\title{
Implementasi Business Intelligent dalam e-Tourism Berbasis Big Data
}

\author{
Chandra Eko Wahyudi Utomo ${ }^{1}$ \\ chandra15@mhs.ee.its.ac.id
}

\begin{abstract}
The use of information technology that is integrated with work processes in an organization has become an absolute necessity. The availability of complete, correct and accurate data and information has become a basic requirement for the survival of an organization. Business Intelligence (BI) is a form of implementation that is able to answer the above needs. BI has been widely used by organizations in managing data and information to support decision making. BI is usually associated with efforts to maximize the performance of an organization. Business Intelligence System is a term that is generally used for the type of application or technology used to assist BI activities, such as collecting data, providing access, and analyzing data and information about company performance. Along with the rapid online-based information systems including e-tourism, creating a huge data explosion on the internet (bigdata). The very high growth of tourism data on the internet can be utilized for the needs of the tourism industry and research needs in the field of tourism.
\end{abstract}

Keywords: intelligent business, e-tourism, big data

\begin{abstract}
Abstrak
Penggunaan teknologi informasi yang terintegrasi dengan proses pekerjaan di suatu organisasi sudah menjadi kebutuhan mutlak. Ketersediaan data dan informasi yang lengkap, benar dan tepat sudah menjadi kebutuhan pokok bagi kelangsungan hidup suatu organisasi. Business Intelligence (BI) merupakan salah satu bentuk implementasi yang mampu menjawab kebutuhan di atas. BI telah banyak digunakan oleh organisasi-organisasi dalam mengelola data dan informasi sampai dengan dukungan pengambilan keputusan. BI biasanya dikaitkan dengan upaya untuk memaksimalkan kinerja suatu organisasi. Business Intelligence System merupakan istilah yang umumnya digunakan untuk jenis aplikasi ataupun teknologi yang digunakan untuk membantu kegiatan BI, seperti mengumpulkan data, menyediakan akses, serta menganalisa data dan informasi mengenai kinerja perusahaan. Seiring dengan pesatnya sistem informasi berbasis online termasuk e-tourism, menciptakan suatu ledakan data di internet yang sangat besar (bigdata). Pertumbuhan data pariwisata di internet yang sangat tinggi ini dapat dimanfaatkan bagi kebutuhan industri pariwisata dan kebutuhan riset di bidang kepariwisataan.
\end{abstract}

Kata Kunci: business intelligent, e-tourism, big data

${ }^{1}$ Mahasiswa magister Telematika di Institut Teknologi Sepuluh Nopember (ITS) Surabaya 


\section{Pendahuluan}

$\begin{array}{llr}\text { Dewasa } & \text { ini } & \text { penggunaan } \\ \text { teknologi } & \text { informasi } & \text { yang }\end{array}$
diintegrasikan dengan proses pekerjaan di suatu organisasi sudah menjadi kebutuhan mutlak. Hal ini dikarenakan adanya kebutuhan dari organisasi tersebut untuk meningkatkan kemampuannya dalam menganalisis masalah-masalah yang dihadapinya serta dalam pengambilan keputusan. Ketersediaan data dan informasi yang lengkap, benar dan tepat sudah menjadi kebutuhan pokok bagi kelangsungan hidup suatu organisasi.

\section{Business Intelligence}

merupakan salah satu bentuk implementasi yang mampu menjawab kebutuhan di atas. BI telah banyak digunakan oleh organisasi-organisasi dalam mengelola data dan informasi sampai dengan dukungan pengambilan keputusan. BI biasanya dikaitkan dengan upaya untuk memaksimalkan kinerja suatu organisasi. Business Intelligence System merupakan istilah yang umumnya digunakan untuk jenis aplikasi ataupun teknologi yang digunakan untuk membantu kegiatan BI, seperti mengumpulkan data, menyediakan akses, serta menganalisis data dan informasi mengenai kinerja perusahaan, yang bergerak di berbagai sektor dan bidang.

Kemajuan teknologi membawa dampak yang luar biasa bagi pariwisata. Dulu, orang melakukan perjalanan wisata bermodalkan uang cash dan informasi dari surat kabar dan televisi. Seiring dengan perkembangan teknologi informasi yang pesat, sekarang orang lebih memilih mencari informasi pariwisata melalui internet dan berangkat berwisata cukup dengan membawa sedikit uang. Peran internet bagi dunia pariwisata sangat terlihat jelas pada keberadaan media sosial online. Hampir semua pengguna internet yang menjadi wisatawan akan meliput dan mengunggah destinasi wisata yang dikunjunginya. Keberadaan media sosial yang sedemikian terbuka menjadikan destinasi wisata menarik akan dikunjungi oleh wisatawan setelah melihatnya di media sosial tersebut. Demikian pula dengan sisi kepraktisan, wisatawan umumnya hanya berbekal seperlunya saja terutama bekal uang saku. Hal ini dikarenakan transaksi keuangan saat ini sudah dapat dilakukan melalui mobile banking dan aplikasi online, di samping hampir di setiap tempat wisata sudah menjamurnya gerai ATM sebagai tempat pengambilan uang yang praktis.

Perubahan perilaku wisatawan ini terjadi di zaman sekarang seiring dengan berkembangnya industri pariwisata. Industri pariwisata masa kini sudah bersentuhan dengan teknologi informasi. Pariwisata sudah menjadi sebuah industri yang digarap secara profesional. Dalam implementasinya, industri pariwisata memanfaatkan teknologi informasi dan komunikasi dalam hal pemasarannya. Strategi pemasaran destinasi wisata sudah sedemikian gencarnya dilakukan, termasuk penggunaan influencer.

Menurut (Poerwanto dalam Mandjusri dan Irfan: 2018) strategi menggunakan influencer bisa diaplikasikan sebagai strategi promosi pariwisata. Silahkan di-search traveller terkenal yang aktif mengulas, mengupload foto dan video travelling-nya dan memiliki banyak followers. Bahkan beberapa sudah mempublikasikan perjalanannya dalam bentuk buku ataupun feature dokumentasi video. Travellers tersebut bisa dimanfaatkan sebagai influencer bisnis pariwisata. Strategi pemasaran dalam dunia bisnis dan perdagangan berbasis internet atau media online 
disebut e-commerce. Ada sektor $e$ commerce yang muncul dalam pariwisata, yang disebut $e$-tourism.

Berdasarkan

data

www.internetworldstats.com, pada 2012, populasi pengguna internet di dunia adalah 2,4 miliar. Juga, menurut laporan tren perjalanan Dunia ITB, internet kini telah dengan jelas memantapkan dirinya sebagai tempat utama untuk membeli perjalanan dengan $54 \%$ pemesanan, jauh di atas agen perjalanan yang telah merosot ke $24 \%$. Kini, menurut laman yang sama (https://www.internetworldstats.com/st ats.htm), populasi pengguna internet sudah mencapai 4,4 miliar.

\section{Grafik 1. Pengguna Internet di Dunia per Juni 2019}

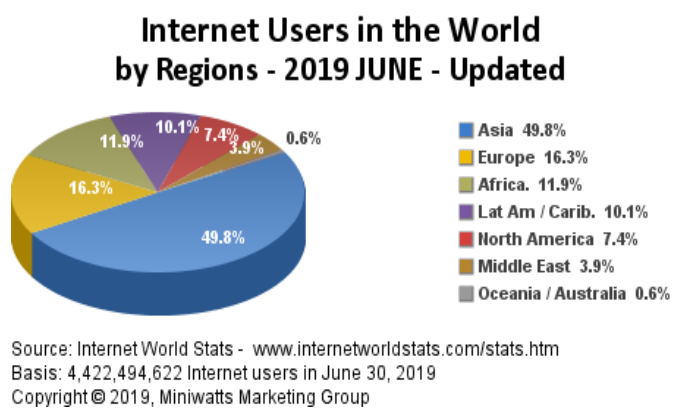

Sumber berita: Internet World Stats - www.internetworldstats.com/stats.htm

Peningkatan akses internet ternyata menciptakan sebuah populasi data yang meningkat pula. Populasi data yang sangat besar di internet dikenal dengan istilah big data. Gagasan "Big Data" (BD) telah menjadi semakin populer ketika banyak orang menjadikan big data tersebut sebagai database yang berguna untuk penelitian. Sehingga dalam beberapa tahun terakhir ini, topik big data banyak tersaji baik di media akademik dan non-akademik.

Konsep big data telah menghasilkan sesuatu ledakan nyata, terutama di internet-internet dan media sosial. Berdasarkan pengamatan penulis saat penulisan artikel ini, pencarian Google menggunakan istilah "Big Data" diperoleh lebih dari 6.570 juta kata. Ketika pencarian Google menggunakan 2 istilah; e-tourism dan big data diperoleh lebih dari 200 juta kata dan selanjutnya diperoleh lebih dari 26 juta kata untuk 3 istilah; $e$ tourism, big data dan business intelligent. Istilah big data ini mengidentifikasi volume besar baik data terstruktur maupun data tidak terstruktur yang dihasilkan oleh perkembangan teknologi dan semakin meningkat secara eksponensial. Mengutip (Verhoef et al., 2016) bahwa penggunaan perangkat jaringan, seperti tablet dan smartphone, telah membawa ledakan data, seringkali terhubung dengan konten yang dibuat pengguna yang berasal dari jejaring sosial online (Leung et al., 2013). Mengingat volume dan karakteristiknya, BD sulit untuk memproses dengan menggunakan metode statistik tradisional dan teknik perangkat lunak (Chen et al.,2014). Namun demikian, BD menjadi cepat populer sebagai bidang penyelidikan baru yang muncul juga dalam ilmu sosial, di mana ia telah diidentifikasi sebagai faktor yang tak tergantikan untuk memecahkan masalah sosial (Mayer-Schönberger dan Cukier, 2013) serta pendorong utama untuk 
penciptaan nilai bagi perusahaan dan pelanggan (Verhoef et al., 2016). Big data dalam bidang pariwisata menjadi fenomena baru dalam kajian dan riset yang akan datang. Pengaruh tumbuhnya internet pada perilaku pengguna, tawaran instrumen yang efisien untuk agen pariwisata dalam mengembangkan dan mendistribusikan penawaran secara global adalah hal yang menarik bagi munculnya teknologi baru dalam dunia pariwisata.

Tulisan ini bertujuan untuk menyajikan pengenalan tool analyzer business intelligent dan pengetahuan baru dalam hal analisis data besar (big data) pada e-tourism yang dapat diimplementasikan pada bidang pariwisata. Di samping itu, juga bertujuan untuk membuka cakrawala baru dalam penelitian akademik di bidang perhotelan dan pariwisata, dengan mengidentifikasi kesenjangan penelitian dan perkembangan masa depan dan merancang agenda untuk penelitian masa depan.

Studi ini terdiri dari tinjauan literatur kuantitatif dari artikel akademik terindeks pada database Scopus dan Web of Science. Tulisan ini berkontribusi untuk mengeksplorasi secara mendalam sejauh mana praktisi pariwisata, sarjana pariwisata dan pihak-pihak terkait dengan kepariwisataan sadar dan bekerja dengan sengaja bahwa implementasi $e$ tourism sedang mengarah pada business intelligent dan big data di era teknologi informasi dan komunikasi (TIK) terkini.

\section{Kajian Pustaka}

\section{e-Tourism}

Istilah e-tourism belum ada yang mengetahui dari mana asal mulanya. Pengertian $e$-Tourism menurut (Pan, $\mathrm{B}$ : 2015) juga dikenal sebagai $e$-travel, $e$ - tourism mengacu pada fenomena dan bidang penelitian di mana adopsi TIK oleh wisatawan dan bisnis mengubah proses dan rantai nilai dalam industri pariwisata. Sedangkan (Buhalis: 2003) mengemukakan bahwa e-tourism mencerminkan digitalisasi semua proses dan rangkaian nilai dalam industri pariwisata, perjalanan, perhotelan dan katering. Pada tingkat taktis, ini termasuk e-commerce dan diterapkannya TIK untuk memaksimalkan efisiensi dan efektivitas dari kepariwisataan. Pada tingkat strategis, e-tourism merevolusi semua proses bisnis, seluruh nilai serta hubungan strategis organisasi pariwisata dengan semua pemangku kepentingan mereka.

Konsep e-tourism mencakup semua fungsi bisnis (misalnya $e$ commerce, e-marketing, e-finance, dan e-accounting, eHRM, e-procurement, $e R \& D$, e-produksi) serta e-strategi, $e$ planning dan e-management untuk semua sektor industri pariwisata, termasuk pariwisata, perjalanan, transportasi, rekreasi, perhotelan, kepala sekolah, perantara dan organisasi sektor publik. Karenanya, $e$ tourism menyatu bersama tiga disiplin ilmu yang berbeda: manajemen bisnis, sistem informasi dan manajemen, dan pariwisata.

$$
\text { e-Tourism adalah suatu cara }
$$

membangun hubungan komersial (terutama penjualan) menggunakan internet untuk menawarkan produkproduk terkait pariwisata: penerbangan, pemesanan hotel, sewa mobil dan sebagainya. Mengenai aplikasi $e$ commerce, jenis layanan ini menurut (Arturo Montejo-Ráez: 2011) diklasifikasikan ke dalam kategori business-to-customer (B2C), karena pelanggan akhir ada di sisi lain transaksi. Dua tema diidentifikasi sebagai dasar pembentukan riset dalam 
domain e-tourism: kemajuan teknologi dan dampaknya terhadap pasar pariwisata. Dari beberapa definisi diatas, dapat dipahami bahwa e-tourism adalah analisis, desain, implementasi dan penerapan solusi teknologi informasi dan e-commerce di industri perjalanan dan pariwisata. e-Tourism adalah penerapan TIK pada industri pariwisata.

E-tourism memberikan peluang untuk melakukan ekspansi bisnis di semua geografis, pemasaran dan operasional. Akibat perkembangan internet, sejumlah pemain baru telah datang ke pasar pariwisata. Mungkin perubahan yang paling signifikan adalah pertumbuhan maskapai bertarif rendah yang menggunakan internet sebagai mekanisme distribusi utama untuk penjualan langsung.

Perkembangan e-tourism telah mendidik konsumen bahwa mereka hanya dapat menemukan tarif murah jika mereka langsung berkomunikasi dengan pembawa informasi online dimana hal ini mengancam baik pembawa informasi tradisional / perusahaan maupun seluruh sistem distribusinya (misalnya GDS dan agen perjalanan). Sama halnya dengan pengembangan agensi eTravel utama seperti Expedia, Travelocity, Lastminute, Orbitz, dan Opodo telah menciptakan pemasaran yang kuat untuk konsumen. Mereka menyediakan solusi perjalanan terintegrasi dan berbagai macam layanan bernilai tambah, seperti panduan tujuan, laporan cuaca dan asuransi. Dengan mengadopsi kemasan dinamis (misalnya kemampuan mengemas perjalanan yang disesuaikan berdasarkan kemampuan individu dengan harga diskon), mereka secara efektif mengancam peran operator tur dan pengusaha pariwisata lainnya.

\section{Business intelligent}

Menurut Howson, sebuah permulaan kumpulan teknologi yang fokus pada BI dimulai pada awal tahun 1990-an. Tentu saja proses pengambilan keputusan telah hadir beberapa tahun sebelumnya, misalkan teknologi yang membantu para manajer untuk mengambil keputusan kapan pemesanan bahan baku dengan teknik peramalan (forecasting) seasonal based forecasting. Pada masa lalu, bahkan sekarang ini masih sering digunakan, para pemimpin perusahaan sering mengandalkan pengambilan keputusan berdasarkan insting, dimana insting ini dipercaya lebih valid dan terpercaya daripada menggunakan tools. Hal tersebut bukan semata-mata tools yang tidak bisa mengejar ketertinggalan hasil yang diinginkan, akan tetapi lebih kepada batasan kemampuan para pemangku kepentingan dalam perusahaan yang menginginkan proses sederhana dalam pengambilan keputusannya, karena dalam perkembangannya sebelum konsep big data (dari algoritma penyelesaiannya dan alat yang mendukungnya dapat diakses dan beredar di pasaran) hadir memenuhi kebutuhan sebagai solusi.

Hal ini dapat disimpulkan bahwa pada masa itu, proses pengambilan keputusan menggunakan alat kecerdasan buatan sangat sulit dilakukan, karena didasarkan pada proses komputasi dan perhitungan data yang sangat lama dan tidak fleksibel. Peledakan data (Big Data concept) telah memaksa BI tools menjadi sangat kompetitif, seiring dengan perkembangan teknologi komputer dan internet yang pesat.

Perusahaan menggunakan Business Intelligence untuk memahami, meningkatkan kinerja, penganggaran biaya yang lebih efisien dan 
mengidentifikasi peluang bisnis baru. Beberapa hal kegunaan Business Intelligence, antara lain:

- Analisis dalam perilaku konsumen, pola pembelian dan tren penjualan

- Mengukur, melacak dan memprediksi penjualan dan kinerja keuangan

- Penganggaran, perencanaan keuangan dan peramalan

- Mengetahui kinerja kegiatan pemasaran

- Optimalisasi proses dan kinerja operasional

- Meningkatkan efektivitas pengiriman dan pasokan

- Analisis CRM Relationship Management)

- Analisis Resiko

- Analisis nilai strategis

- Analisis media sosial

Jika pada lembaga bisnis (profit organization) business intelligence dimanfaatkan untuk meningkatkan kinerja melalui pemilihan strategi bisnis yang tepat, maka pada lembaga pemerintahan (non-profit organization) business intelligence dapat digunakan untuk meningkatkan kinerja perusahaan melalui peningkatan efisiensi pelaksanaan kerja sehingga pada akhirnya akan tercipta perbaikan layanan pada masyarakat serta pengelolaan anggaran yang tepat. Business Intelligence juga dapat membantu suatu perusahaan dalam menganalisis perubahan tren yang terjadi sehingga akan membantu perusahaan menentukan strategi yang diperlukan dalam mengantisipasi perubahan tren tersebut.

Pentingnya internet sebagai media massa di bidang pariwisata adalah bahwa ia merupakan saluran penting lembaga pemasaran dan jaringan bisnis tujuan wisata. Tetapi sangat sedikit proses selanjutnya manajemen,

pemeliharaan, peningkatan, dan eksploitasi penampilan ini dipelajari secara mendalam. Interaktif sifat situs web, sebagai pengirim informasi dan penerima, telah menarik perhatian para sarjana sejak itu interaksi memungkinkan pembukaan pendekatan baru untuk mempelajari lalu lintas jaringan (halaman yang telah dikunjungi pengguna, dipesan) mereka, waktu yang telah ada di dalamnya, tindakan yang dilakukan dan perilaku siber. Informasi mengalir dari fisik ke dunia cyber, dan sebaliknya, mengadaptasi dunia konvergen ke perilaku manusia dan dinamika sosial.

\section{Big Data}

Menurut laman Tech Terms, ungkapan "big data" sering digunakan dalam pengaturan perusahaan untuk menggambarkan sejumlah besar data. Itu tidak merujuk pada jumlah data tertentu, melainkan menggambarkan suatu dataset yang tidak dapat disimpan atau diproses menggunakan perangkat lunak database tradisional.

Wikipedia menerjemahkan Big Data ke dalam bahasa Indonesia dengan Mahadata. Kamus Besar Bahasa Indonesia (KBBI) belum memasukkan istilah big data ataupun mahadata dalam entrinya. Data, menurut KBBI, artinya keterangan yang benar dan nyata; keterangan atau bahan nyata yang dapat dijadikan dasar kajian (analisis atau kesimpulan); informasi dalam bentuk yang dapat diproses oleh komputer, seperti representasi digital dari teks, angka, gambar grafis, atau suara.

Bigdata atau Mahadata adalah istilah umum untuk segala himpunan data (data set) dalam jumlah yang sangat besar, rumit, dan tak terstruktur sehingga menjadikannya sukar ditangani apabila hanya menggunakan 
perkakas manajemen basis data biasa atau aplikasi pemroses data tradisional. Gartner IT Glossary mendefinisikan Big Data sebagai berikut: Big Data is high-volume, high-velocity and/or high-variety information assets that demand costeffective, innovative forms of information processing that enable enhanced insight, decision making, and process automation.

\section{Karakteristik Big Data}

IBM di situs resminya menyebutkan, big data memiliki tiga karakteristik utama:

\section{Volume}

Volume di sini berkaitan dengan ukuran media penyimpanan data yang sangat besar atau mungkin tak terbatas. Big data memiliki jumlah data yang sangat besar sehingga dalam proses pengolahan data dibutuhkan suatu penyimpanan yang besar dan dibutuhkan analisis yang lebih spesifik.

\section{Velocity}

Big data memiliki aliran data yang yang cepat dan real time. Velocity dapat diartikan sebagai kecepatan proses.

\section{Variety}

Big data memiliki bentuk format data yang beragam baik terstruktur ataupun tidak terstruktur dan bergantung pada banyaknya sumber data. Variety berarti tipe atau jenis data yang dapat diakomodasi.

\section{Contoh Big Data}

Contoh big data termasuk indeks pencarian Google, database profil pengguna Facebook, dan daftar produk Amazon.com. Kumpulan data ini (atau "datasets") sangat besar sehingga data tidak dapat disimpan dalam database biasa, atau bahkan komputer tunggal.
Awalnya Big Data adalah sebuah sistem teknologi yang diperkenalkan untuk menanggulangi 'ledakan informasi' seiring dengan semakin bertumbuhnya ekosistem pengguna perangkat mobile dan data internet. Pertumbuhan perangkat mobile dan data internet ternyata sangat mempengaruhi perkembangan volume dan jenis data yang terus meningkat secara signifikan di dunia maya. Berbagai jenis data, mulai data yang berupa teks, gambar atau foto, video hingga bentuk data-data lainnya membanjiri sistem komputasi.

Di sektor bisnis Big Data, Google bisa dikatakan sebagai pelopor. Tahun 2006, Google sempat memperkenalkan Google Bigtable. Bigtable merupakan sistem database berskala besar dan cepat yang digunakan Google untuk mengolah berbagai jenis data dari berbagai layanan, termasuk data dari layanan mesin pencari berbasis internet. Facebook juga menerapkan sistem database sejenis untuk menangani melonjaknya pengguna layanan mereka. Dengan teknologi Big Data, media sosial milik Mar Zuckerberg ini tak pernah kesulitan untuk menangani peredaran data yang melonjak drastis yang berasal dari satu miliar penggunanya. Contoh big data lainnya, perusahaan asuransi di Jepang mengumpulkan informasi tentang perilaku mengemudi kliennya dengan memonitor GPS.

Dari pengumpulan informasi ini tidak hanya data tentang umur, jarak tempuh, jenis perizinan, namun juga dengan mengetahui keadaan mengemudi setiap kliennya, perusahaan asuransi tersebut mampu menganalisis risiko setiap kliennya dan memastikan margin harga yang sesuai. Perusahaan dapat menggunakan informasi dari media media seperti 
Facebook dan Twitter, untuk menganalisis bagaimana perilaku, persepsi pelanggan terhadap suatu produk atau brand dari perusahaan.

\section{Pembahasan}

\section{Perilaku Pengguna Internet pada 2019}

Cara orang menggunakan internet juga berkembang dengan cepat, dengan akuntansi seluler untuk bagian yang semakin meningkat dari aktivitas online. Menurut Hootsuite, secara spesifik penggunaan ponsel dan aplikasi di bagian seluler khusus di bawah ini, tetapi perlu dicatat di sini

bahwa telepon seluler sekarang hampir separuh waktu yang dihabiskan orang di internet.

Rata-rata, pengguna internet dunia menghabiskan 6 jam dan 42 menit online setiap hari. Angka itu turun sedikit pada angka tahun lalu 6 jam dan 49 menit, tetapi penurunan ini mungkin sebagian karena sejumlah besar pengguna baru yang masih belajar cara menggunakan internet, dan yang menggunakan internet kurang dari para pengguna yang lebih berpengalaman yang beralih ke perangkat mereka yang terhubung ratusan kali setiap hari.

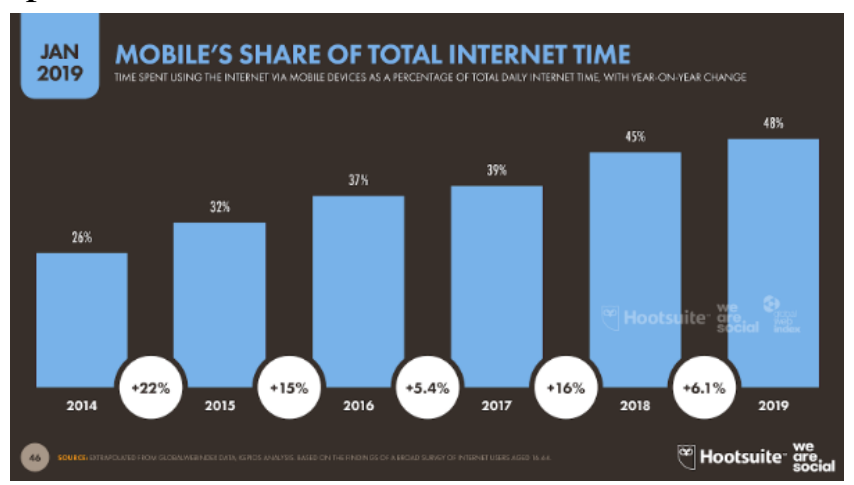

\section{Grafik 2. Pengguna Internet dalam Menghabiskan Waktu untuk Berselancar}

\section{Perilaku Pengguna Media Sosial pada 2019}

Jumlah waktu yang dihabiskan orang di media sosial telah meningkat lagi tahun ini, meskipun sangat sedikit. GlobalWebIndex melaporkan bahwa rata-rata pengguna media sosial sekarang menghabiskan 2 jam dan 16 menit setiap hari di platform sosial naik dari 2 jam dan 15 menit tahun lalu - yang setara dengan sekitar sepertiga dari total waktu internet mereka, dan sepertujuh dari total waktu internet online.
Perlu dicatat bahwa waktu yang dihabiskan untuk media sosial berbedabeda antar budaya, dengan pengguna internet di Jepang menghabiskan ratarata hanya 36 menit untuk media sosial setiap hari. Di ujung lain dari skala, Filipina terus menghabiskan waktu paling banyak di media sosial, dengan rata-rata tahun ini 4 jam dan 12 menit mencerminkan peningkatan 15 menit per hari (6 persen) dibandingkan ratarata yang dilaporkan tahun lalu. 


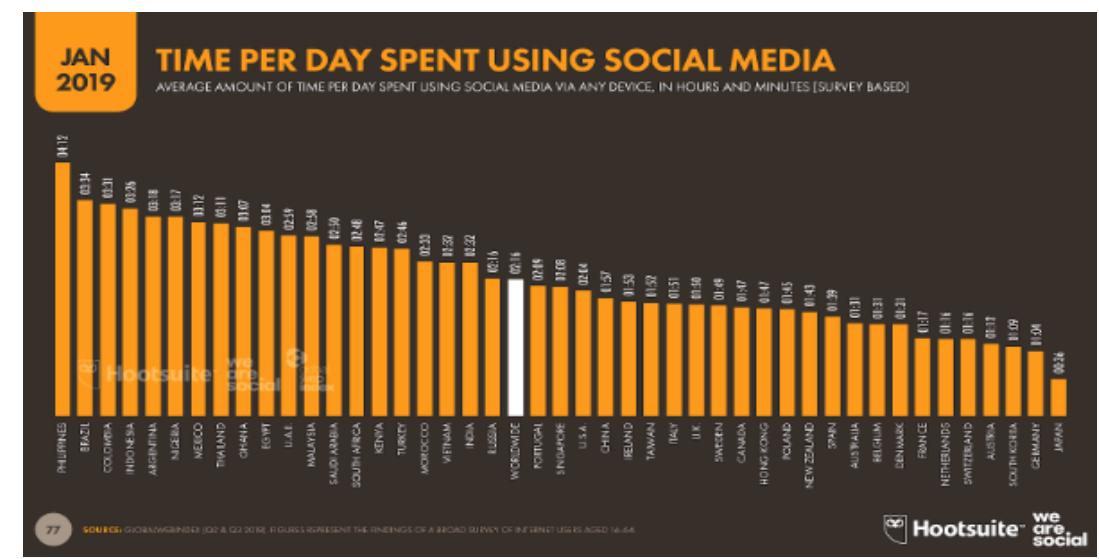

\section{Grafik 3. Pengguna Internet dalam Menghabiskan Waktu untuk Bermedia Sosial}

Penerapan aplikasi modern dalam pengolahan data yang bersumber dari internet sudah saatnya dilakukan. Ledakan data di dunia maya sebagaimana hasil riset menunjukkan bahwa pertumbuhan data yang sangat tinggi setiap harinya membuat tool analyzer konvensional tidak sanggup mengatasinya. Oleh karena itu, perlu diatasi dengan tool yang setara atau yang cocok dengan jumlah data yang sangat besar (big data) tersebut. Unggahan foto, video dan sejenisnya yang begitu banyak dan hampir dilakukan oleh para wisatawan di setiap tempat wisata dari berbagai negara menjadikan suatu sumber data yang sangat berguna jika diolah dan dipresentasikan.

Dalam dunia teknologi informasi terkini, business intelligent merupakan solusi jitu bagi kebutuhan untuk mengolah, mempresentasikan dan meramalkan kedepan suatu destinasi wisata atau kondisi kepariwisataan di suatu daerah tertentu terutama dalam lingkup e-tourism. E-Tourism memiliki subdomain-subdomain yang implementasinya berbeda-berbeda. Adapun subdomain-subdomain dalam e-tourism menurut (Buhalis: 2011) yang berpotensi sebagai sumber data, antara lain: $e$-Airlines, e-Hospitality, $e$ Tour operators, e-Travel agencies dan
e-Destinations. Sumber ledakan data juga berasal dari media sosial yang tumbuh sangat pesat di hampir seluruh negara di dunia. Koleksi Global Digital 2019 terbaru We Are Social dan Hootsuite mengungkapkan bahwa pengguna internet tumbuh rata-rata lebih dari satu juta pengguna baru setiap hari, dengan semua 'Pengguna Miliaran Berikutnya' yang asli sekarang online.

\section{Dukungan Business Intelligent pada e-Tourism}

Implementasi business intelligent dalam pengolahan big data sudah dilakukan oleh banyak praktisi teknologi informasi. Umumnya mereka menggunakan tool-tool analyzer bigdata seperti Pentaho, BIRT, YellowFinn, dan sebagainya. Sehingga big data pada e-tourism pun dapat menggunakan tool ini. Adapun sekilas tentang beberapa tool analyzier BI adalah sebagai berikut:

\section{Pentaho}

Pentaho adalah kumpulan aplikasi Business Intelligence (BI) yang berkembang dengan pesat dan bersifat free open source software (FOSS) yang berjalan di atas platform Java. Pentaho merupakan produk komersial 
open source Business Intelligence (BI), sebagai alternatif solusi implementasi BI dengan biaya terjangkau. Pentaho menyediakan aplikasi untuk Data Integrasi (Extract, Transform, and Loads / ETL Tools) dan Dashboard Analytics.

\section{BIRT}

BIRT singkatan dari Business Intelligence and Reporting Tools, merupakan aplikasi open source milik Eclipse yang dirilis pertama kali pada tahun 2004. BIRT disponsori oleh Actuate dan menerima kontribusi dari IBM dan Innovent Solutions. Saat ini platform teknologi BIRT adalah salah satu visualisasi data yang paling banyak digunakan untuk BI dengan lebih dari 12 juta download dan lebih dari 2,5 juta pengembang di 157 negara. BIRT juga memiliki komunitas pengembang besar, aktif dan berkembang mewakili semua jenis organisasi. Perusahaan teknologi besar seperti IBM, Cisco, S1 dan ABS Sistem Nautical telah dimasukkan BIRT dalam lini produk mereka.

\section{SpagoBI}

SpagoBI adalah perangkat lunak opensource Business Intelligence, open source milik SpagoWorld, didirikan dan didukung oleh kelompok insinyur yang menawarkan berbagai macam fungsi analitik, lapisan semantik yang sangat fungsional yang seringkali tampil di platform open source dan proyek, dan mendukung fitur visualisasi table set dari data advance termasuk geospasial analytics.

SpagoBI dirilis di bawah lisensi Umum Mozilla, memungkinkan penggunaan komersial. SpagoBI host pada OW2 Forge dikelola oleh konsorsium OW2, komunitas perangkat lunak open source yang independen.

\section{Open Source BI Tools: Code Name "TACTIC"}

TACTIC adalah dinamis, open source, platform berdasar web yang digunakan untuk membangun solusi menengah (business enterprise), dimana TACTIC ini mengintegrasi Digital Asset Management (DAM), Content Management (CMS), dan Workflow Management untuk menciptakan sebuah aplikasi yang lengkap yang berguna untuk memberikan solusi pemrosesan data perusahaan. Goal dari TACTIC adalah untuk memberikan platform bagi workline yang beraneka ragam. Kekuatan TACTIC berada pada fleksibilitas open source yang berguna meningkatkan adaptasi pengguna ketika melakukan kustomisasi aplikasi tersebut, sehingga diharapkan solusi yang tercipta dari proses ini dapat tepat guna menyentuh sasaran permasalahan.

TACTIC dibuat berdasarkan payung southpawtech.com pada tahun 2015 oleh Gary Mundell dan Remko Noteboom, dua veteran dari industri komputer grafis. Bisnis mereka memberikan solusi untuk kasus-kasus pemrosesan data-data bisnis yang digunakan untuk membantu para manajer dan stakeholder perusahaan mengambil keputusan. Aplikasi ini didesain pada mulanya untuk pasar media dan entertainment. Semua teknologi Southpaw dibuat berdasarkan platform open source TACTIC dan sehingga membutuhkan Lisensi Elipse. Selain itu tidak dibutuhkan lisensi apapun untuk menjalankan aplikasi ini. 

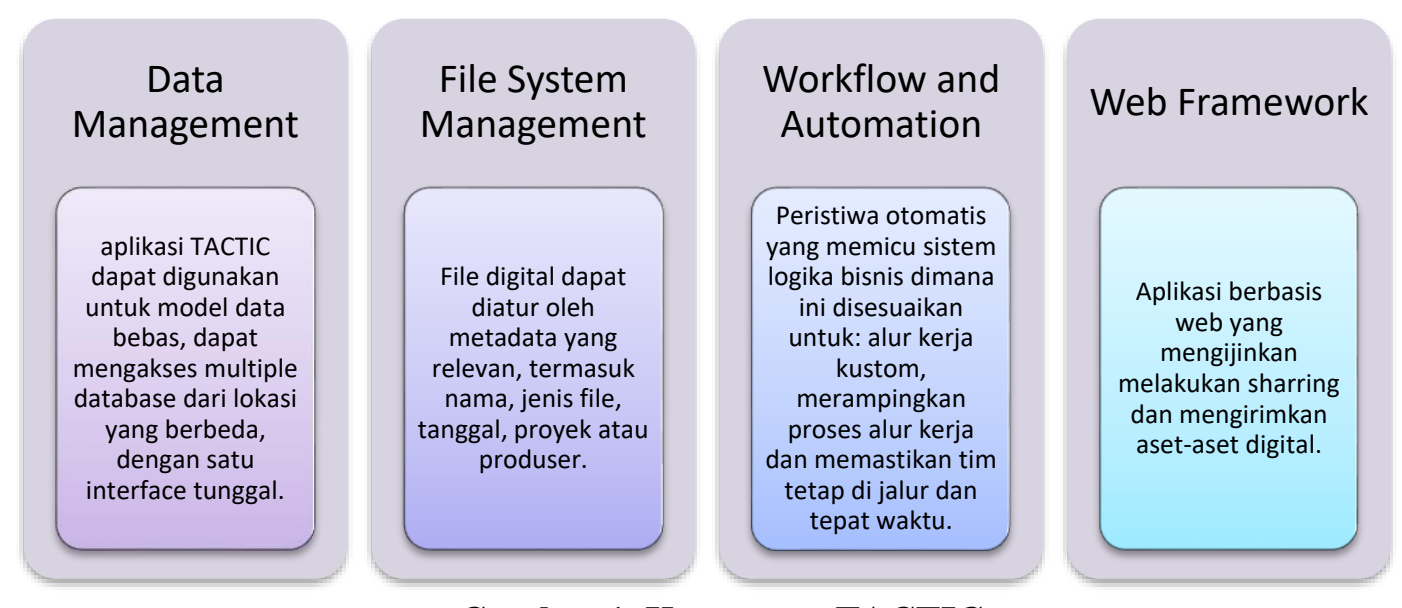

\section{Gambar 1. Komponen TACTIC}

Karena didesain untuk lingkungan kerja yang sibuk dengan konten trafik yang besar. TACTIC streamline menerapkan logika bisnis untuk data dan sistem data lingkungan yang berbeda dan dinamis memvisualisasikan setiap aspek melalui pengiriman berbasis web. Platform ini memadukan unsur-unsur DAM, PAM, CMS dan teknologi ECM, menawarkan pengguna satu set alat untuk membuat berbagai solusi alur kerja perusahaan disesuaikan atau aplikasi proses pintar.

\section{JasperReports}

JasperReports merupakan library open source berbasis Java yang dapat memenuhi berbagai kebutuhan dalam membuat laporan, yang outputnya dapat berupa: PDF, HTML, Microsoft Excel, RTF, ODT , Comma-separated values (CSV), ataupun file XML.

Pada situr resminya ada installer Jaspersoft Studio, JasperReports Server, iReport. Dengan kegunaan masing - masing memiliki yaitu :

a. Jaspersoft Studio: Software ini berbasis Eclipse yang nantinya digunakan untuk mendesain berbagai report.

b. iReport : Sebenarnya tidak ada bedanya dengan Jaspersoft Studio, kegunaannya sama-sama untuk mendesain report.

c. JasperReports Server : Adalah server apps, yang artinya aplikasi ini berjalan di server dan di akses lewat browser sehingga dapat di integrasikan dengan aplikasi web lain.

JasperReports memiliki keunggulan atau kekhasan dari sisi fitur, diantaranya:

- Memiliki tata letak laporan yang fleksibel.

- Mampu menyajikan data tekstual atau grafis.

- Memungkinkan developer untuk menyediakan data dalam berbagai cara.

- Dapat menerima data dari beberapa sources data.

- Dapat menghasilkan watermark.

- Dapat menghasilkan subreports.

- Mampu meng-eksport laporan ke berbagai format.

\section{Pengolahan Big Data Menggunakan Tool Business Intelligent}

Sistem Business Intelligent berbasiskan internet memungkinkan organisasi untuk melakukan tindakan proses bisnis cerdas yang peka waktu dan bermanfaat secara analitik. Sehingga dapat memberikan peluang 


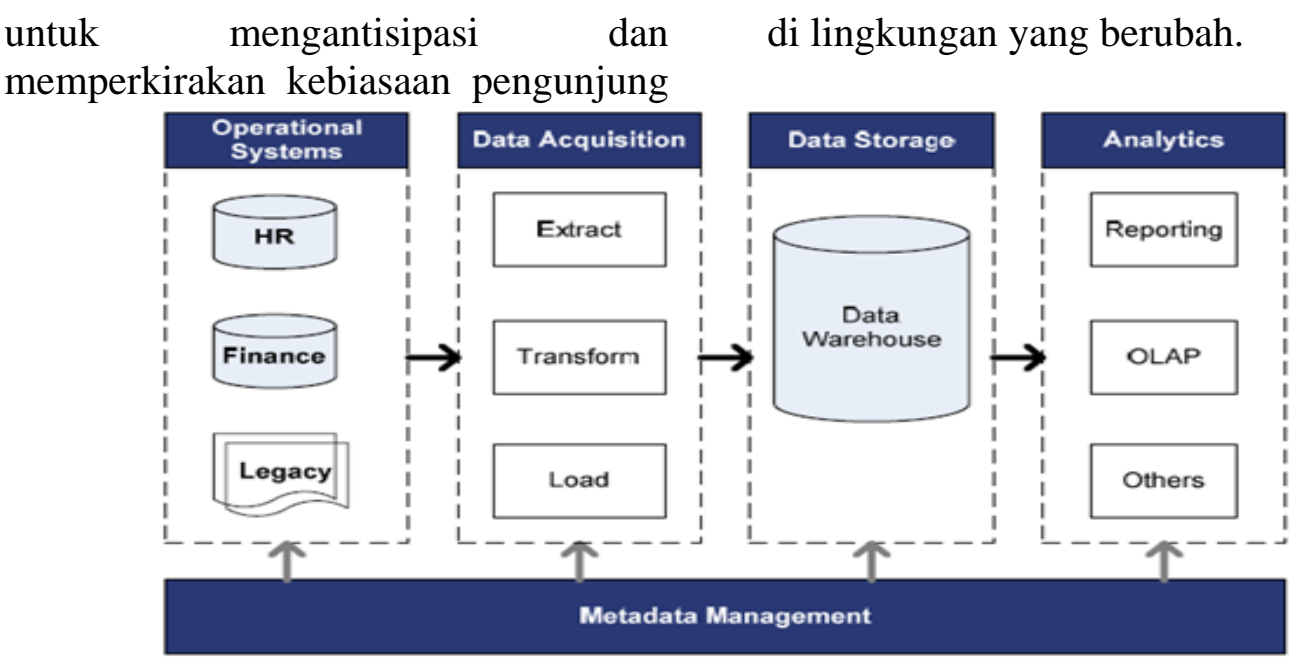

Gambar 2. Arsitektur Sistem Business Intelligence secara Umum Sumber : Niu, 2009.

Pengolahan data besar (big data) pada e-tourism dapat menggunakan tool business intelligent dan salah satunya yaitu Pentaho. Berikut ini contoh mengolah big data menggunakan pentaho:

\section{Koneksi ke Server}

Untuk koneksi ke server terlebih dahulu pengguna harus Koneksi Tunnelling ke server melalui SSH

\section{Instal Pentaho}

Sebelum meng-install pentaho, lakukan instalasi Java terlebih dahulu untuk bahasa pemrograman, baru lakukan instalasi pentaho. Lakukan instalasi Pentaho di Server instansi setempat. Selanjutnya, diberi penamaan server dimana koneksi dengan menggunakan Putty. Lalu, dibuat otorisasi hak akses ke server terkait username dan password pengguna.

\section{Konversi Data}

Berkas big data dikonversi terlebih dahulu menjadi file berformat .xml menggunakan Data Integration. Setelah mesinnya siap, file diupload dan diedit ke dalam Pentaho.

\section{Upload Data ke Pentaho}

Klik pada "Create New" kemudian klik pada pilihan "Analysis Report”, sehingga kita akan mendapatkan tampilan sebagai berikut ini:

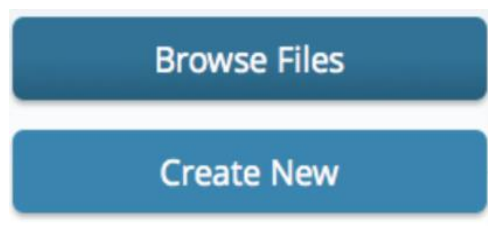

\section{Manage Data Sources}

\section{Analysis Report}

Interactive Report

\section{Gambar 3. Menu pada Analysis Pentaho}

Dalam pemilihan "Data Source" kotak dialog, kemudian dapat dipilih input data sembarang, dalam contoh kasus ini kami 
menggunakan input data pribadi dengan melakukan link terhadap database.

\section{Integrasi Data di Pentaho}

Aplikasi Pentaho sangat mungkin untuk menggunakan mesin learning technologies, seperti penggunaan mesin berbasis bahasa R, WEKA, dan Python. Tiap-tiap bahasa ini diintegrasikan dengan eksekutor pada plugin PDI. Pada gambar di bawah ini dapat dilihat, bagaimana WEKA digunakan untuk membuat klasifikasi sebuah data set, dimana outputnya diinputkan pada Pentaho.

Komponen data mining dalam pentaho menggunakan Weka Knowledge Flow(s) dapat dieksekusi sebagai berikut:

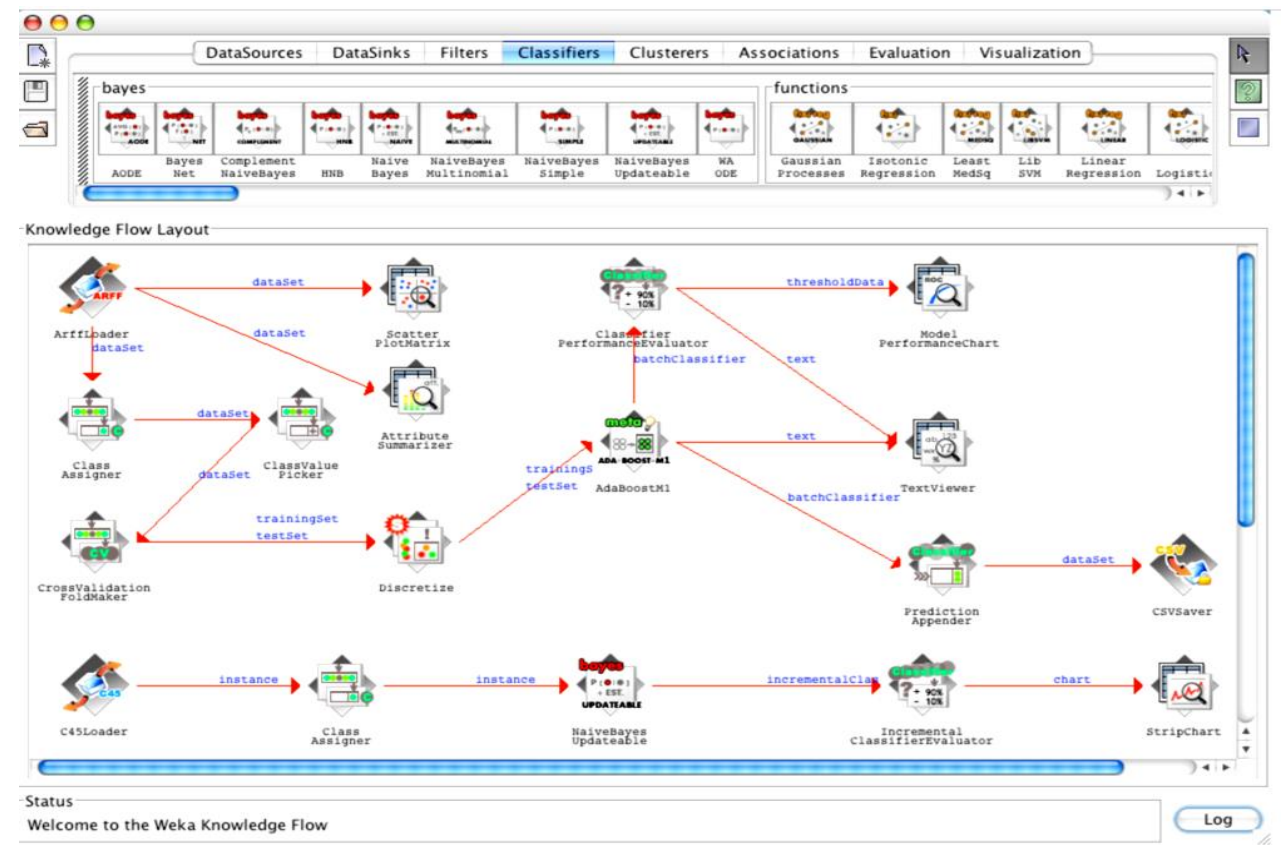

Gambar 4. Weka Knowledge Flow dalam Pentaho

Dari localhost dapat di-setting pada developer examples, mengenai bagaimana konfigurasi pentaho dan Weka.

\section{Analisis Data di Pentaho}

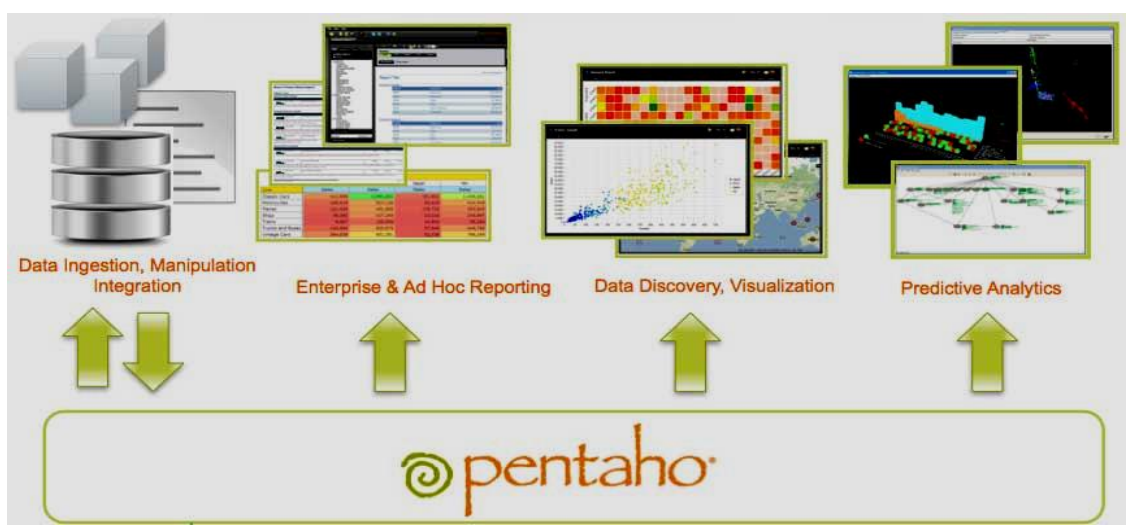

Gambar 5. Output dari Analisis Pentaho 
Secara garis besar Pentaho dibagi menjadi empat kemampuan analisis, yaitu Data Integrasi dan manipulasi, Reporting, Penemuan data dan visualisasi, dan Analisis Prediktif.

Implementasi business intelligent pada e-tourism dapat dilakukan berdasarkan sub-domainnya, diantaranya adalah sebagai berikut:

\section{E-Airlines}

Dunia penerbangan memiliki data yang besar yang dapat dikelola dan dianalisis untuk kepentingan bisnis pariwisata dimana jadwal penerbangan biasanya disesuaikan dengan animo wisatawan yang berkunjung di suatu destinasi wisata tertentu. Dalam tool analyzer-nya dapat diolah data jumlah wisatawan menjadi perkiraan jumlah pengunjung lokasi wisata tertentu tahun depan atau paket wisata dengan diskon besar-besaran dalam momen-momen tertentu setiap tahunnya.

\section{E-Hospitality}

Hotel menggunakan TIK untuk meningkatkan operasi mereka, mengelola inventaris mereka dan memaksimalkan profitabilitas mereka. Sistem mereka memfasilitasi manajemen dan distribusi internal melalui media elektronik. 'Property Manajemen System (PMS)' mengkoordinasi resepsionis, penjualan, perencanaan dan fungsi operasional dengan mengatur reservasi dan mengelola inventaris hotel.

\section{E-Tour Operators}

Business Intelligent dalam eTour Operators sepertinya juga dapat dilakukan dengan cara mendata operator-operator tour dan pengaturan jadwal serta pembagian wilayah bisnis. Pelancong liburan sering membeli "paket," yang terdiri dari penerbangan charter dan akomodasi, diatur oleh operator tur. Operator tur cenderung memesan di muka produk-produk ini dan mendistribusikannya mereka melalui brosur yang ditampilkan di agen perjalanan. Makanya, hingga saat ini di negara-negara Eropa Utara, dimana wisata operator mendominasi peluang pasar yang masih longgar tersebut, perusahaan penerbangan dan hotel adalah jarang digunakan untuk perjalanan liburan. Thomson.co.uk misalnya telah mengembangkan strategi online yang komprehensif untuk memberikan informasi yang kaya media di situs web-nya. Perusahaan ini mendukung podcasting dan videocasting dan juga telah terintegrasi Goggle Map yang menyajikan informasi data di situs miliknya. Mereka menggunakan teknologi yang secara inovatif akan dapat memberikan nilai kepada klien mereka dan menjaga posisi mereka di pasar.

\section{E-Travel Agencies}

Implementasi pengolahan big data juga dapat berguna bagi agen perjalanan dimana mereka dapat mengontrol perilaku wisatawan yang melakukan perjalanan wisata di suatu daerah dan negara tertentu. Analisis datanya dapat berupa pemetaan wisatawan berdasarkan usia dan kemampuan keuangan yang dimiliki sebagai bahan promosi wisata. Atau juga dapat dipakai dalam hal menaikturunkan harga tiket demi laba perusahaannya.

\section{E-Destinations}

Implementasi BI di e-destination dapat dilakukan dalam hal paket wisata. Lokasi wisata menarik yang terkumpul di suatu wilayah tertentu dapat dijadikan suatu paket kunjungan wisata dalam tarif tertentu. Juga, pengolahan data jumlah kunjungan di setiap objek wisata dapat diramalkan dalam sepuluh tahun kedepan dan halhal apa saja yang menarik di suatu 
destinasi wisata tertentu. Untuk data yang sangat besar dimana setiap tahun bertambah, analisis datanya pasti tidak mungkin diatasi dengan metode konvensional meski itu dinamis atau dengan sistem informasi online, namun lebih dari itu dengan menggunakan tools yang sanggup menampung data yang sangat besar, apalagi jika sampai harus menampung data-data lama digabung dengan data destinasi wisata yang terkini.

\section{Manfaat Business Intelligent dalam Industri Pariwisata}

Manfaat utama dari penerapan BI dalam industri pariwisata adalah sistem ini sangat berorientasi pada pengguna. Istilah pengguna disini dapat diartikan sebagai pengelola destinasi wisata, pemerintah maupun pihak swasta yang bergerak di bidang industri wisata yang menggunakan e-tourism. Artinya keterlibatan personil TI maupun karyawan/staf perusahaan atau pegawai pemerintahan dalam proses pengolahan data menjadi minimal karena seluruh proses pembuatan report (laporan) maupun distribusinya dapat dilakukan oleh pengguna (user). Produktivitas user juga menjadi meningkat karena dapat menyelesaikan tugas beragam output tanpa banyak bergantung kepada personil TI.

Dibandingkan dengan cara lama yang menggunakan MS Excel, pengguna dapat menghasilkan lebih banyak informasi dan dapat dilakukan dalam waktu yang lebih singkat. Seperti halnya penggunaan reporting tools open source untuk penerapan BI. Sehingga sesuai pertumbuhan data di era milenial ini, terutama untuk data yang sangat besar (big data), penggunaan aplikasi business intelligent dalam mengolah dan menganalisis data kepariwisataan adalah langkah yang solutif dan terbaik.

\section{Kesimpulan}

E-Tourism sebaiknya diposisikan sebagai alat dalam mengembangkan industri pariwisata di era ICT terutama dalam hal penyediaan informasi dan pemesanan paket wisata oleh wisatawan. E-Tourism juga dapat mengurangi travel agen luar, sehingga semua pendapatan dari pengeluaran wisatan menjadi hak pariwisata Indonesia. Berdasarkan ketersediaan berbagai aspek seperti akamodasi, objek wisata, fasilitas untuk mendukung aktivitas wisatawan dan adanya informasi yang lengkap tentang jarak perjalanan dan didukung oleh kecocokan harga dan waktu, maka akan sangat membantu wisatawan untuk mengambil keputusan didalam melakukan perjalanan ke Indonesia.

Business intelligent sebagai tool dalam mengembangkan $e$-tourism yang berbasis big data mengingat pertumbuhan data di internet yang sangat pesat. Business intelligent digunakan untuk menganalisis dan memperkirakan perkembangan pariwisata dari suatu sumber data yang sangat besar (big data) untuk beberapa tahun ke depan.

\section{Daftar Pustaka}

Arturo Montejo-Ráez, J. M.-O.-C.-S. (2011), Otium: A web based planner for tourism and leisure. Expert Systems with Applications(38), 10085-10093.

Buhalis, D. (2003). eTourism: Information Technology for Strategic Tourism Management. London, UK: Pearson (Financial Times/Prentice Hall). 
Buhalis, D. and Jun, SH. (2011). eTourism. CONTEMPORARY TOURISM REVIEWS. Goodfellow Publishers Limited, Woodeaton, Oxford

Chen, M., Mao, S. and Liu, Y. (2014), "Big data: a survey", Mobile Networks and Applications, Vol. 19 No. 2, pp. 171-209.

Condratov, Iulian. 2013. e-tourism: Concept and Evolution, ECOFORUM Volume 2, Issue 1(2) page 58. Romania.

Howson, C., 2008. Business Intelligence : Secret to Making BI a Killer App. s.l.:McGraw-Hill.

Leung, R., Rong, J., Li, G. and Law, R. (2013), "Personality differences and hotel web design study using targeted positive and negative association rule mining", Journal of Hospitality Marketing and Management, Vol. 22 No. 7, pp. 701-727.

Mandjusri, A. dan Irfan, E. 2018. Pemahaman Praktis Strategi Influencer Promosi Pariwisata. Journal of Tourism and Creativity Vol.2 No.1 Januari 2018. Universitas Jember. Jember.
Mariani, M., etc. 2018. Business intelligence and big data in hospitality and tourism: a systematic literature review. International Journal of Contemporary Hospitality Management. Emerald Publishing Limited.

Verhoef, P.C., Kooge, E. and Walk, N. (2016), Creating Value with Big Data Analytics: Making Smarter Marketing Decisions, Routledge, London.

TACTIC, 2015. community.southpowtech.com.

[Online]

Available at: http://community.southpawtech.co m/tactic-end-user_enduser_interface-map.html [Accessed 27 September 2016].

https://www.internetworldstats.com/sta ts.htm

https://wearesocial.com/blog/2019/01/d igital-2019-global-internet-useaccelerates https://en.wikipedia.org/wiki/BIRT_Pr oject. 